This item was submitted to Loughborough's Research Repository by the author.

Items in Figshare are protected by copyright, with all rights reserved, unless otherwise indicated.

\title{
Coming to terms with communist propaganda: post-communism, memory and generation
}

PLEASE CITE THE PUBLISHED VERSION

https://doi.org/10.1177/1367549416682247

PUBLISHER

SAGE Publications

VERSION

AM (Accepted Manuscript)

\section{PUBLISHER STATEMENT}

This work is made available according to the conditions of the Creative Commons Attribution-NonCommercialNoDerivatives 4.0 International (CC BY-NC-ND 4.0) licence. Full details of this licence are available at: https://creativecommons.org/licenses/by-nc-nd/4.0/

\section{LICENCE}

CC BY-NC-ND 4.0

\section{REPOSITORY RECORD}

Szostak, Sylwia, and Sabina Mihelj. 2019. "Coming to Terms with Communist Propaganda: Post-communism, Memory and Generation”. figshare. https://hdl.handle.net/2134/22522. 


\title{
Coming to Terms with Communist Propaganda:
}

\section{Post-communism, Memory and Generation}

\author{
Sylwia Szostak and Sabina Mihelj \\ Loughborough University
}

\begin{abstract}
This article has two main aims. First, it seeks to contribute to existing research on the mediation of post-communist memory by considering the Polish case and specifically by focusing on audience memories of an iconic television series produced in communist Poland, Four Tankmen and a Dog (TVP, 1966-1970), set during World War Two. Second, the article pays particular attention to the generational stratification of audience memories, and thereby makes a contribution to recent literature that examines the links between generation and mediated remembering. The analysis draws on life-course interviews with viewers of two different generations, conducted in Poland in 2014. The results indicate that the ways in which Polish audiences remember communist-era programming, and specifically the extent to which they perceive such programming as propaganda, vary significantly with generation. We argue that these differences stem from generationally-specific experiences in the past, which gave rise to distinct modes of engaging with the communist era and its heritage.
\end{abstract}

Keywords: memory, generation, post-communism, post-socialism, propaganda, television, World War Two

Over the course of the late 1980s and the 1990s, the gradual weakening of communist rule in Eastern Europe triggered a heightened interest in representations of the past which shows no signs of abating. In this sense, we could say that Eastern Europe joined what Andreas Huyssen (1995) refers to as the 'memory boom of unprecedented proportions' that swept across the most technologically advanced societies in the West during the 1980s. The boom in memory was manifested in the public sphere through a growing prominence of public debates over the past, official commemorations, oral history projects, as well as through a proliferation of new museums and memorials across post-communist Eastern Europe (e.g. Bernhard and Kubik 2014, Mark 2010, Sarkisova and Apor 2008, Todorova, Dimou and Troebst 2014).

This post-communist memory boom has been amply documented in, and constituted through, different types of mass communication. Over the past few years, research on the mediation of memory in Eastern Europe has grown considerably, and tackled a number of topics and media genres, ranging from nostalgia and trauma and from television to the new media (e.g. Imre 2016: 155-172, Kapczynski 2007, Khinkulova 2012, Rutten, Fedor and Zvereva 2013, Volčič 2007). Increasingly, researchers interested in the mediation of memory in the post-communist world are also engaging with questions of vernacular memory, and using audience research as the starting point of their investigation (e.g. Kaun and Stiernstedt 2012, Lepp and Pantti 2013, Reifová 2015, Reifová, Gillárová and Hladík 2012, Reifová and Hladík 2013). A similar tendency can be observed in the literature on media and memory more generally, which 
initially centred on general theoretical debates and privileged textual or institutional analysis over audience research. However, over the years, several authors have emphasised the importance of considering the audience perspective, and the volume of work on the mediation of personal and vernacular memory has grown considerably (e.g. Bourdon 2003, Bourdon and Klingler-Vilenchik 2011, Carvalheiro and Silveirinha 2015, Dhoest 2007, Keightley 2011, Penati 2013, Volkmer 2006).

This paper has two broad aims. Its first aim is to contribute to the growing body of work on the mediation of memory in the post-communist context by considering the Polish case, and specifically by focusing on audience memories of an iconic communist-era television series, Czterej Pancerni i Pies, hereafter Four Tankmen and a Dog (TVP, 1966-1970). The case study seeks to show how communist television heritage becomes involved in the broader processes of coming to terms with the communist past. During communist rule, television was an important source of information, education and entertainment, but it also functioned as an instrument of propaganda, used by the Party to promote its agenda. For this reason, television programmes created in this period are rarely remembered simply as objects of cultural heritage; instead, they become sites of contention over the communist past and its meaning for post-communist societies. Yet, our analysis also shows that it would be misleading to interpret the vernacular memories of communist-era television simply through the prism of contemporary controversies. Rather, we argue that these memories are to an important extent shaped by different historical experiences with communism. More specifically, we argue that different generational cohorts experienced communism and its television in different ways, and that these generationally specific experiences in part account for the diversity of postcommunist memories.

This brings us to the second aim of our article, which is to contribute to the small but growing literature that tackles the links between generation and mediated memory (Bolin 2014, Maass and González 2005, Ramsay 2015, Volkmer 2006). While mnemonic differences between generational cohorts are routinely noted in existing literature, they are rarely examined in their own right. Our article seeks to show that there is much to be gained from paying more attention to the generational dynamics of mediated memory. Among other things, we argue that a focus on generational differences can help us overcome the tendency to presentism that often dominates memory research, and acknowledge not only how the present shapes the past, but also how the past informs and constrains the ability of the present to rewrite the past.

In what follows we first situate our study vis-à-vis existing literature on generation, memory and the media. This is followed by a section that provides more information on communist television and the series Four Tankmen and a Dog, and by a discussion of methodology. The remainder of the article presents and discusses the results of the analysis.

\section{Memory, Generation and the Media}

As Debra Ramsay (2015: 39) rightly points out, 'generation is a slippery and multivalent term' that is often used to denote quite different ideas. The conceptual confusion surrounding the term typically results from 'a lack of differentiation between the effects of birth cohort, age and life cycle' (Anonymised 2014: 453). One the one hand, the term generation can be used to refer to individuals born around the same historical point in time, i.e. a birth cohort; on the other hand, it can be used to denote belonging to an age group, such as the 'younger generation' or the 'older generation'; finally, it may also be used in the context of family 
relations, for instance when talking about the generations of grandparents, parents and children within the same family. Conflating the different can easily lead us to mistake what is effectively a universal characteristic of old age for a characteristic of a particular generational cohort. To avoid such problems, we should clarify that this article understands generations as birth cohorts, i.e. groups of people born around the same point in history.

Existing research on generation and memory often turns for inspiration to the classic study of developed by Karl Mannheim (1952). Mannheim likens belonging to the same generation to belonging to the same class, arguing that both "endow the individual ... with a common location in the social and historical process, and thereby limit them to a specific range of potential experience' (p. 291). As a result, individuals belonging to the same generational cohort (or class) become predisposed 'for a certain characteristic mode of thought and experience, and a characteristic type of historically relevant action' (ibid., p. 291). Of particular importance in this context, argues Mannheim, are experiences that occur during a given generation's formative years, which Mannheim identifies as the late teenage years and early adulthood. Events and experiences encountered during this formative period, argues Mannheim, coalesce into 'a natural view of the world', and all the subsequent experiences gained over the course of the lifetime achieve meaning from it, appearing either as its confirmation or its negation (ibid., p. 298).

A range of empirical studies on generation and memory informed by Mannheim's insights confirmed his arguments to be correct. Schuman and Scott (1989), for instance, used a national sample of adult US citizens to show that the historical events they found most memorable were usually those they experiences during adolescence and early adulthood. A similar result was reached by Jennings and Zhang (2005), who used interviews with a probability sample of inhabitants in different locations in China, even though the effect of generational cohorts seemed less pronounced among Party cadres than among other inhabitants. Finally, qualitative research on the vernacular memories of the Iron Curtain, conducted by Anonymised (2014), also showed that Mannheim's arguments can, with some modifications, offer a useful starting point for examining post-communist memory.

At the same time, subsequent research also suggested important modifications to Mannheim's classic theory. One of the ideas relevant to this article is the one developed, among others, by Pickering and Keightley (2012), who maintain that memorable experiences shared by particular generational cohorts do not necessarily need to be based on first-hand experiences, but can also be linked to events that occurred before that generation's lived experience. This phenomenon was explored in depth by Marianne Hirsch (1996: 659) in her work on 'postmemory', understood as 'the experience of those who grow up dominated by narratives that preceded their birth, whose own belated stories are evacuated by the stories of the previous generation, shaped by traumatic events that can neither be fully understood nor recreated'. While Hirsch developed the concept to describe the mnemonic experiences of children of Holocaust survivors, there is reason to suggest that the notion of postmemory has wider applicability. As we shall see, citizens born in communist Eastern Europe after World War Two grew up in the shadow of the war, and their perceptions of the world, including the media and the Four Tankmen and a Dog, were to an important extent coloured by these 'prosthetic' memories, developed in conversation with accounts of the war passed on by their older relatives, or via the media.

How do these general arguments about generation and memory relate to the mediation of memory? Two main approaches can be distinguished. The first largely follows Mannheim in 
understanding generations as social formations defined by their shared location in historical and social process, which endows them with access to specific potential experiences. In line with this, it has become common among media scholars to talk of 'media generations' - that is, birth cohorts defined by the particular media ecology that dominated their adolescence and early adulthood (e.g. Gumpert and Cathcart 1985, Westlund and Weibull 2013). Based on this, some media scholars have argued that memories of past engagement with the media are likewise shaped by the media environment one grew up with. A comparative study of media memories across three generations, led by Volkmer (2006), showed that different generations remembered international media events differently, depending on whether they experienced them primarily through radio, television, or other media. Taking a somewhat different perspective, Bolin (2014) examined the intimate relationships that members of the same generation often develop with the specific reproduction technologies they grew up with, such as comics or the vinyl record, and investigated how these intimate relationships shape the memories of one's past engagement with the media. Drawing on focus groups interviews conducted in Sweden and Estonia, he reveals a clear generational stratification of media memories, and highlights the formative role of childhood experiences with the media.

The second approach to the generational patterns of mediated memory is found in Ramsay's (2015) investigation of the mediated memories of World War II. In contrast to approaches inspired by Mannheim, Ramsay builds on the work of Aboim and Vasconcelos (2014) and treats generations as discursive constructs and 'as dynamic constructs that are shaped, like memory, through networks of mediated narratives, images, and belief systems' (pp. 8-9). In line with this, she is interested in examining how different media industries, genres and texts, from film and television serials to video games, produce discourses that seek to define successive generations. She does so by focusing on the mediated depictions of World War II across different media genres and texts produced at different points in time and aimed at different generations. As shown in her analysis, the discursive constructs of generations are markedly selective, and highlight specific elements of historical events or experiences of a generational cohort at the expense of others.

The research presented in this article follows the first approach, in the sense that it treats generations as age cohorts whose members had access to the same potential experiences, including experiences involving the media. Yet, we also acknowledge that the television series that stands at the centre of analysis can be seen as a media text that contributed to the formation of generations as discursive constructs. More specifically, this series, set in World War Two, offered a particular (selective) reading of the generational experience of the war. As we shall see, this reading contrasted with the historical reality of the war actually experienced by the wartime generation, as well as with the often traumatic memories of the war that this generation passed on to those born during the 1940s and the 1950s. In this sense, the analysis presented here indicates that the study of generational memory as a mediated discursive construct can be combined with the study of the social stratification of mediated memory across age cohorts. Because of the restrictions of space, however, the focus of the analysis is not on the TV series itself but on generational cohorts, and on the ways in which they shape vernacular memories of the communist-era TV programme.

\section{Communist television fiction and Four Tankmen and a Dog}

Much as its West European cousin, communist television was seen as an important vehicle of information, as well as a means of education, cultural refinement and entertainment. In fulfilling these goals, however, communist broadcast professionals also had to ensure that 
their work remained aligned with the Party agenda. In line with this, the Polish Communist Party envisioned a variety of roles for television: raising the society in the spirit of socialism, engendering patriotism, combating foreign ideologies and foreign influences and attitudes, and battling unwanted occurrences in economic, social and cultural life of the nation (RTV Radio i Telewizja 1969). Although the propagandistic functions were particularly clearly apparent in news and current affairs programming, domestically produced fiction was also often enlisted to achieve ideological goals. Historical drama played a particularly prominent role in this context, and became a very successful vehicle for promoting representations of history aligned with Party interests, not only in Poland but across state socialist Europe. As Anikó Imre (2016: 133-154) argues, an important reason for this success lied in the fact that historical fiction allowed communist elites to exploit the appeal of nationalist narratives, at a time when the legitimacy of communist rule was in decline. This mixture of nationalism and communism was clearly apparent also in Poland: according to Janusz Kotański (2004), Polish communist-era historical fiction was meant to shape national consciousness, present the past and national myths in a light consistent with communist ideals, as well as engender national pride. Arguably, Four Tankmen and a Dog was designed to fulfil similar goals, but in the context of a different form of narration - namely, serial television drama.

The Four Tankmen series follows the adventures of a tank crew that comprises two Polish and two Soviet soldiers fighting the German army, with the backdrop of World War Two. The first episode, which shows how the four tankmen first met, premiered on 9 of May 1966, and the remaining 20 episodes were broadcast between 1966 and 1970. At the time of the broadcast, the show gathered an impressive audience and quickly became a cult show (Lukowski 1980). The series was repeated on a regular basis until the 1980s, and in postcommunist Poland, the country's public service broadcaster TVP - formerly the Partycontrolled state broadcaster - continued to broadcast it every year, gathering a viewership of 3 million per episode (Wirtualne Media 2007). The show has also been broadcast by a commercial broadcaster Polsat as well as appeared on the cable channel Kino Polska (Media2.pl 2007), and was released on DVD in 2007.

The resonance of the Four Tankmen and a Dog in present-day Poland is to a large extent a result of its continued re-broadcasting and remediation. However, after 1990, the series became rather contentious: the show began to be widely criticized, especially by conservative political fractions. It was accused of presenting a distorted version of history and inflicting permanent damage to the historical awareness of the Polish nation by omitting crucial information about the Soviet occupation such as the mass murders of Polish AK soldiers, the exile of Polish soldiers to Siberia, and Soviet raids of Polish territory (Kotański 2004). The depiction of Polish history in the show was perceived as deceitful and fabricated for the purpose of erasing the true Polish national heritage (Kotański 2004). In 2000, a local veteran association from Kraków filed a formal complaint to the Polish Broadcasting Council requesting a ban of the show. After this first unsuccessful attempt, the veteran society filed another complaint in 2006. At that time, the Polish public broadcaster was governed by Bronisław Wildstein, a representative of the right-wing conservative political faction, and the political climate was conducive to such anti-communist sentiments (Wirtualne Media 2006). As a result, Four Tankmen and a Dog, along with other communist-era war series such as Stawka Większa Niż Życie (More than Life at Stake, 1968), was taken off air (Piotrowski 2011). With the change of the head of Poland's Broadcasting Council in 2007, the show returned to Polish TV screens and is still being re-broadcast alongside other communist-era programmes. 


\section{Methodology}

The analysis presented in this article is based on interviews with Polish viewers who experienced watching Polish television in the pre-1989 era. A total of thirty-one viewers were interviewed in Warsaw between September 2014 and December 2014, all recruited through direct email requests and through word of mouth. The interviewees can be divided into three generational cohorts, which differ with regard to their experiences of the war, communism, as well as the TV series Four Tankmen - all of which were thought to be relevant to their recollections of the programme. The oldest group comprises six interviewees born before the start of World War Two, who experienced the war first-hand, lived through the transition into communist rule, and encountered the Four Tankmen only in their adult years. The middle group includes fourteen participants born between 1941 and 1959, who had few if any direct personal recollections of the war, but heard about it regularly from the media and from their parents. This generation was fully socialised under communist rule, and reached teenage years or young adulthood when the Four Tankmen first aired. The youngest group comprises eleven interviewees born during the 1960s and the 1970s, for whom the war was a distant historical event, who became acquainted with the Four Tankmen through watching reruns, and who lived through their formative years of late teenage and early adulthood when the communist system was falling apart, and were therefore never fully socialised into it. Among the participants, 20 were female and 11 were male, 15 participants possessed a higher education degree, while 16 had completed primary or secondary level of education. In as much as possible, we have also sought to recruit interviewees of different political orientations, or at least with different attitudes to the communist past.

The interview protocol covered a wide range of aspects of communist-era television, including daily routines, memories of the first TV set, and favourite TV programmes and personalities. The first part of the protocol followed the life history approach, which is now a well-established method in research on mediated vernacular memory (e.g. Bourdon 2003, Bourdon and Klingler-Vilenchik 2011). This part started with open questions about one's memories of watching television, moving from earliest memories (e.g. during childhood) through memories of watching television at different points in the life cycle. The second part of the interview consisted of short clips of Polish programmes used to prompt viewer recollections, including a clip of Four Tankmen and a Dog. The analysis presented in this article focuses on all instances when interviewees discussed the Four Tankmen, either in response to the clip or at other stages in the interview. Other parts of the interviews were taken into account to contextualise the findings about the programme with regard to memories of communism and television more generally.

Three distinct patterns of reactions were identified in the materials, which correspond with the three generational cohorts outlined earlier. Although distinct patterns could be observed for each of the three cohorts, the analysis that follows is limited to the two youngest cohorts. This is in part because of restrictions of space, and in part because the oldest group comprised only six interviewees, of which only four had something substantial to say about the series, which meant that the amount of material was too small to draw firm conclusions. As we shall show, both the first post-war generation, born in the 1940s and the 1950s, and the generation of their children, born in the 1960s and the 1970s, appreciated the dramatic and entertaining qualities of the series. However, while the older generation also regularly mentioned the distorted depiction of history and the propagandistic nature of the show, the younger generation focused almost exclusively on the programme's entertainment value, and either ignored or 
dismissed the political interpretations of the series altogether, or insisted that it should not interfere with the appreciation of the show.

A final note of clarification is in order before proceeding. While focusing on the generational stratification of memory, we do not presuppose the existence of a homogenous set of generational experiences or memories. This was acknowledged already by Mannheim, who claimed that a historical stimulus experienced by a particular generational cohort could give rise to very different intellectual and social responses. Different groups that form part of the same generation can therefore 'work up the material of their common experiences in different specific ways' (1952: 304). Although our analysis cannot do full justice to such intragenerational variation, we do highlight some examples: the different understandings of propaganda and the different ways of justifying one's enjoyment of the Four Tankmen employed by the first post-war generation, and the gendered memories and modes of engaging with the TV programme among the second post-war generation.

These intra-generational differences also indicate that generationally specific experiences and memories can interact with a myriad of other factors, including gender, educational background, and political leanings. However, it is important to underscore that these factors did not over-ride the generational patterns we have identified. For instance, one may expect that interviewees holding anti-communist views or remembering communism in a negative light will necessarily be more disparaging of the Four Tankmen or focus primarily on its propagandistic elements. Yet, our results do not support such a clear-cut link between political orientation and television memory. While some interviewees who expressed anti-communist sentiments indeed remembered the series exclusively as a piece of propaganda (e.g. Pol-211944-malee), others s holding negative views of the pre-1989 era recalled watching the series with pleasure (e.g. Pol-11-1973-female). To be sure, these results are based on a very limited sample, which cannot be considered representative, yet the patterns found are instructive, and suggest that generation is, at least in certain respects, more important in determining approaches to the communist past than political affiliation.

\section{The first post-war generation: Coming to terms with propaganda}

The interviewees born during the 1940s and the 1950s interpreted the Four Tankmen using two main frames: propaganda and entertainment. On the one hand, they remembered enjoying the series and noted its entertaining and dramatic qualities, yet on the other hand, they also discussed its role as a piece of propaganda, or at least noted its distorted representation of historical events. This is not to say that everyone agreed with the designation of the show as propaganda; while some accepted the term as adequate straight away, others insisted that the series should actually be appreciated simply as a good piece of entertainment. For instance, upon being shown a clip from the series, a male interviewee, born in 1944, immediately referred to it as 'propaganda' and then went on to elaborate on the different inaccuracies and ideological intentions if the narrative:

Interviewee: Propaganda.

Interviewer: So you recognize it?

Interviewee: Yes, there are still some re-runs on TV nowadays.

Interviewer: Did you watch it?

Interviewee: I did and I watched it often. Not because of the story but the

performances of the actors and the lies that were shown there, especially the tank Rudy that rose from the dead. It burnt and then it came back to life. There are so many lies in 
this series, but that was propaganda. We needed to see how brave Polish soldiers were and how 'normal' they were: that they were up for a drink and a brawl. [...]

Interviewer: But despite those aspects...

Interviewee: My perception of this series is negative.

Interviewer: But you still watched it...

Interviewee: Yes, because there was nothing else so you would watch anything that was on. This was an action series so it was watched for the entertainment purposes too.

(Pol-21-1944-male)

When pushed by the interviewer to admit that he watched the programme despite its propagandistic qualities, the interviewee accepted that this was indeed the case, but also immediately sought to justify his viewing choices by arguing that he only watched it because there was nothing else on offer. He also acknowledged that Four Tankmen was a piece of entertainment, but used a formulation ('it was watched') that suggests he did not himself prey victim to such propagandistic entertainment.

Other interviewees likewise agreed that the show is ideologically problematic, but did not deny their own enjoyment of the series at the time. Rather, they used different ways of justifying such enjoyment. A particularly common approach was to describe one's pleasure as an integral part of innocent childhood or youth. For instance, a male interviewee argued that at the time, he and his friends simply did not perceive the programme as propaganda:

When it comes to this series... it glorified the Polish-Soviet friendship that never existed; it praised the socialism and so on and that is how it is perceived now... But in 1965 when it started, we watched it as teenagers and we saw it as an adventure series which praised friendship, helping each other out. We didn't see propaganda there.

(Pol-23-1951-male)

In a similar vein, another male respondent acknowledged that in the series, 'the war was showed from the propaganda point of view', but insisted that at the time, 'being young boys, we had no idea about that'. Instead, they were simply attracted to the series as a piece of entertainment that showed interesting war equipment and shootings, and served as inspiration for playground games (Pol-10-1947-male). A female participant, born in 1959, offered a similar justification: 'I watched it as a child so its ideology had no meaning to me' (Pol-141959-female). Again and again, we therefore see childhood and youth featuring as an era of innocence, when ignorance of the propagandistic nature of one's favourite TV programmes was, if not unavoidable, then at least understandable. This is of course not to deny the fact that the interviewees were unlikely to be aware of the ideological messages during childhood. It is, however, interesting and relevant that they felt the need to justify their enjoyment of the series in this way.

One interviewee who remembered watching the series on several occasions and with great pleasure, however, went as far as to reject the charge of propaganda altogether, despite acknowledging the historical inaccuracies.

No doubts, Four Tankmen ... an amazing show. Some people really try to make it political but to me it presents the war in a more positive way and even though it wasn't true to real events it was made for young people and I enjoyed it. [...] I already realized that the war didn't look like that; that it was horrible; and here it was shown in 
a more positive way. I think that this series shouldn't be considered in the political or historical context.

(Pol-13-1951-male)

Of particular interest in this case is the fact that this interviewee grew up with parents who were very critical of the regime and frequently discussed their views with their son. Yet nonetheless, he noted several positive aspects of communist television throughout the interview, and insisted that the Four Tankmen should not be judged simply as a piece of propaganda, but above all as quality entertainment produced for young audiences. As a result, he did not feel the need to justify his own enjoyment of the series, or present it as a result of youthful ignorance. This example serves as another reminder that political convictions and attitudes to communism are not necessarily a good predictor of views on communist-era television programming.

It is also interesting to note that some of the interviewees from this generation did not see propaganda or historical inaccuracies exclusively in negative terms. Rather, the embellished portrayal of war and the propagandistic intentions were sometimes presented as reasons for appreciating the series. Particularly common was the perception of the programme as a welcome 'break' from the more realistic, dark accounts of the war that dominated the postwar decades and were a common topic of both private conversations among family members as well as of public discourses and commemorations of the war. Indeed, the first post-war generation grew up in the shadow of the war, and was permanently surrounded by narratives of suffering and images of brutality, often passed on by their relatives who experienced the conflict first-hand. According to a survey conducted in 1975, as many as 60 percent of respondents from the first post-war generation claimed that their main source of knowledge about the conflict was the family oral tradition (Pawełczyńska 1975). For this generation, the Four Tankmen and a Dog series therefore served as a vehicle of post-memory (Hirsch 1996), yet also presented a welcome departure from traumatic post-memory, and offered a way of engaging with the war that was focused on pleasure and entertainment. The following interview extract reflects this particularly well:

My generation - and I was born in 1947 - grew up with the cult of war. Literature, films and later programmes and stories on TV, everything was about the war trauma and the victory over the Germans. The war for us was something natural - almost like to those who lived through it. We were the first post-war generation. Our parents talked about it. Our parents' friends talked about it. So for us when the war was shown on TV not in its most brutal way but just like it was in Four Tankmen and a Dog - we were really into it.

$$
\text { (Pol-10-1947-male) }
$$

Several other interviewees agreed, emphasizing the appeal and novelty of a more engaging and pleasurable, if inaccurate representation of the war. A male participant, born in 1949, underlined that the show presented the war 'in a more accessible, even jolly way' and 'was more about everyday life than the tragedy of war' (Pol-25-1949-male). In a similar manner, a female interviewee, born in 1948, argued: 'After watching films about war that were difficult, brutal and showed the real war, this series was showing a smoother version. You knew the characters are going to be alright and that they are brave soldiers,' (Pol-17-1948-female). In both cases, the propagandistic, distorted version of history presented in the show was seen as a justification for enjoying the series. 
In sum, the first post-war generation clearly felt compelled to engage with contemporary controversies surrounding the Four Tankmen, and specifically with the perception of the series as a historically inaccurate piece of propaganda. As we have seen, the interviewees responded to these controversies in a variety of different ways. While some accepted the charge of propaganda without hesitation, others argued that the series should be remembered and valued primarily as a good piece of entertainment, and listed several of its outstanding qualities. Accounts of one's own enjoyment of the series of the past varied accordingly. Some participants sought to deny any sense of enjoyment when watching the series in the past; others presented their past pleasures as an unavoidable and excusable part of youthful innocence and ignorance; and yet others simply insisted that the series was an example of quality entertainment and it was therefore appropriate to enjoy it as such. Also notable is the fact that some interviewees saw the programme's propagandistic qualities and inaccuracies especially its embellished, sanitised representation of life during the war - as a positive trait and as a reason for enjoying the series at the time. This made sense in the particular context of the post-war years, when the first post-war generation was surrounded by a permanent stream of traumatic, harrowing accounts of the war experiences, and craved for a different mode of engaging with the past.

\section{The second post-war generation: War as Entertainment}

For the interviewees born after 1960, the historical falsification and propaganda that featured so prominently in the memories of the first post-war generation was only a marginal issue. The Four Tankmen was remembered and evaluated almost exclusively as a piece of entertainment, cherished for its engaging depiction of love and friendship, and for providing an inspiration for playground games. In contrast to the first post-war generation, interviewees born during the 1960s and the 1970s rarely mentioned the controversial aspects of the series spontaneously, and even when prompted by the interviewer, they typically refused them as irrelevant to their engagement with the programme. The following excerpt from an interview with a female participant born in 1973 offers a case in point:

Interviewee: Oh, Czterej pancerni i pies.

Interviewer: Do you have any memories from watching it?

Interviewee: Well Czterej pancerni i pies was a cult show of our times. All girls had a crush on Janek Kos and all boys fancied Marusia. I always liked Pola Raksa and I still do. I remember we used to play and pretend we are the characters from it.

Interviewer: So watching it was a big event too? You talked about it with your friends and so on?

Interviewee: Yes.

Interviewer: Tell me what you liked about it?

Interviewee: I liked everything about it.

Interviewer: Was it the historical aspect or something else?

Interviewee: Well... I don't think I paid much attention to the historical aspect of it. I liked the characters and the adventures they had and that was it, I think.

Interviewer: So you saw it more like an adventure series?

Interviewee: Yes, exactly. I knew it was about war and I knew what was going on in it but I didn't pay much attention to it.

(Pol-06-1973-female) 
The majority of other interviewees from the same cohort reacted in much the same way, with gendered inflections. While female viewers typically recalled enjoying the romantic plot and the emphasis on friendship, male participants gave preference to the depictions of battles and explosions. Much as the viewer we have just encountered in the excerpt, another female interviewee born in 1973 remembered being 'interested in people's relationships; who was in love with whom and so on' (Pol-04-1973-female), while another recalled re-enacting scenes from the series with her nursery friends, where 'all the boys wanted to be Janek, and most of girls wanted to be Marusia, who was in love with Janek' (Pol-02-1973-female). Another female interviewee from the same cohort described the show as designed for young boys, and hence less attractive to her as a girl. She claimed she liked 'the adventures and the love story', but was 'put off' by the war and was not curious at all about the aspects of the show that attracted her male peers (Pol-19-1974-female). In contrast, a male participant born in 1974 remembered that he 'identified with Janek, the guy driving the tank' (Pol-01-1974-male), while another recalled watching the programme 'as an adventure series for a boy; it was great, lots of shooting, a tank; they always won' (Pol-08-1972-male).

None of these interviewees had much to say about the controversial aspects of the series, even when explicitly prompted by the interviewer to comment on the series' depiction of historical events or its role in promoting communist values. One claimed that 'it's hard for me to talk about history here', and then went on to discuss what she liked about the show (Pol-04-1973female), while others simply stated they had no interest in the history aspect or that this aspect had nothing to do with how they actually perceived the programme (Pol-04-1973-female, Pol07-1963-male). The same applied when issues of propaganda or ideology were raised. One participant insisted that she 'didn't see any propaganda messages in it' and 'just watched it because I liked it' (Pol-05-1971-female), while another argued that he 'didn't see any socialist messages in it' and 'just watched it as an adventure series' (Pol-08-1972-male).

These reactions may seem superficially similar to those seen among older interviewees, who also recalled watching the show purely as a piece of entertainment. However, while interviewees from the first post-war cohort then went on to criticise the series and sough to justify their past enjoyment of the programme as part of childhood naivety and ignorance, participants from the younger cohort did not seem to see anything problematic in their perception of the series, and indeed seldom had much to say about propaganda.

On rare occasions when interviewees from the younger cohort spent more time reflecting on the controversial aspects of the series, they either sought to deny the charges as irrelevant altogether, or accepted them as accurate but insisted that they should not interfere with the enjoyment of the series. The following excerpt provides a case of denial; the interviewee finds the interpretation of the series as a propaganda tool wholly unpersuasive, and insists that the show should not be judged for its political messages:

No one really cared that this show is a false depiction of history. I can't imagine how nationalistic and patriotic you would have to be to discard Four Tankmen and a Dog and say that the show depicts the enslavement of Poland by the Soviet army. I honestly doubt it. Maybe only the people who lost their loved ones by the hands of the Soviets. I did not know one single person who would be critical of Four Tankmen and a Dog for the political messages contained in the show. For me, Four Tankmen and a Dog are removed from the political domain.

(Pol-12-1961-male) 
A female interviewee, on the other hand, was more open to accepting the criticisms of the series and acknowledged that it historical distortions, but nonetheless insisted that this awareness has little impact on her continued enjoyment of the programme:

I was quite surprised to learn that I fell for the Soviet propaganda because for me it was a beautiful television series about the Polish-Russia friendship and about the common fight. Only later on I started collecting and processing information about facts that I was not aware of, such as the violence of Russian soldiers against Polish women. And that the friendship was somewhat forced. So now I do not treat the show seriously when it comes to its depiction of history but still when I come across it on telly I still see the very same things I did in the past, such as the beautiful girl Marusia who is in love with the Polish and I do not mind. So I still see the show in terms of human relationships and not propaganda. The political or historical aspects of the series are still of no interest for me. I still nurture the approach I had to the series when I was a child and I want it to remain this way.

(Pol-11-1973-female)

Much as the interviewees from the older cohort, this participant clearly distinguishes between her earlier, more naive and ignorant perception of the series, and the current, more informed understanding of its political messages. Yet, unlike the respondents from the older cohort, she seems to feel no need to question her childhood attitudes to the show, and in fact wants to continue enjoying the series as she always did. It is also worth noting that the extent of engagement with political controversies surrounding the Four Tankmen did not vary with the level of education; in fact, one of the interviewees who discussed the historical inaccuracies and ideological messages of the series more extensively attained a lower level education than the rest of the cohort.

Arguably, the reluctance to engage with the controversial aspects of the series among the younger generation reflects their rather distant, disengaged attitude to the communist past. Compared to the generation of their parents, the cohort born during the 1960s and the 1970 reached the formative period of late teenage and early adulthood at a time when the legitimacy and stability of communist rule in Poland was in decline, or when the country was already undergoing a rapid transition to a liberal democracy and market economy. As a result, members of this generation were not fully socialised into a communist system, and hence do not perceive communism as a part of their own past. In line with this, they also do not feel the urge to critically engage with communism, or question their own past practices and attitudes. The burden of coming to terms with the communist past is simply not their own burden - it is a task for the generation of their parents, who, as we have seen, spontaneously engaged with the controversies surrounding the Four Tankmen, and evidently felt the need to either deny or justify their past enjoyment of the series.

A contributing factor may be the fact that the events of World War Two depicted in the series hold rather little personal and emotional significance for the younger generation. In contrast to the older generation, who grew up in the shadow of the war and surrounded by family accounts of war-time experiences, interviewees born during the 1960s and the 1970s learned about the war in a less personalised manner, through the media or in school. Indeed, research conducted in the mid-1970s confirms that for youngest audiences at the time, television and film constituted the main sources of information about World War Two (Pawełczyńska 1975). This is a clear departure from the post-war generation, which not only grew up in an era when the war was prominently present in the public realm, but also learned about the events through 
first-hand accounts of personal experiences provided by their relatives. In such a context, it was more likely for the older generation to interpret the Four Tankmen as a programme that, while entertaining and enjoyable, was also linked to historical events. In contrast, the younger generation largely ignored the historical references embedded in the programme - and hence the ideologically problematic messages - and perceived it almost exclusively as an adventure series and a love story of the programme.

\section{Conclusions}

The idea that memory is always reconstructed to serve the needs of the present is central to most theories of memory. Yet, an exclusive focus on the capacity of the present to remould the past can give rise to an overly presentist understanding of memory, and lead us to neglect the ways in which our engagement with the past is shaped by historical circumstances and experiences. The nature of historical experiences with communism will depend on a myriad of factors, including one's gender, socio-economic background, political leanings and other circumstances. In this article, we have focused on the impact of generationally specific experiences, a factor that has so far attracted rather limited attention in media and memory research.

To investigate the generational dynamics of mediated memory, we have examined the vernacular memories of the popular TV serial Four Tankmen and a Dog. As shown in the article, two dominant mnemonic frames can be detected: one that sees the programme as a piece of propaganda and emphasises its historical distortions and ideological messages, and another that highlights the entertainment nature of the programme and its dramatic qualities. Our analysis suggests that the two frames are distributed unevenly across the two generations examined here: although all interviewees appreciated the value of the series as a piece of entertainment, those born during the 1940 and the 1950s also discussed the propagandistic intentions and historical inaccuracies of the series, while those born during the 1960s and the 1970s largely bypassed the topic or dismissed it as unimportant. As we have argued, these differences stem from the disparate, generationally specific historical experiences with communism. Older interviewees, who were born during the 1940s and the 1950s, came of age when communist rule was firmly in place, and lived the majority of their adult lived under communism, evidently perceive the period as an integral part of their past and of who they are. As a result, they also felt compelled to engage with the controversies surrounding the communist era, reflect on their own involvement with the regime and, in our case, justify their past enjoyment of propagandistic programming. In contrast, younger interviewees, who were born during the 1960s and the 1970s, never fully accepted communism as a prominent part of their own past, and hence did not feel compelled to engage with its controversial aspects, nor justify their childhood engagement with propaganda-infused programming.

The results have implications for the broader field of research on media and memory, as well as for debates surrounding post-communist memory. First, with regard to the field of media and memory, our research illustrates the value of focusing on generation as a social factor shaping mediated memory, and also demonstrates the importance of developing a more historically sensitive approach to memory formation, and resisting the appeal of presentism. Second, with regard to post-communist memory, our case study highlights the importance of the generational dynamics in coming to terms with the communist past. Because the nature of communist rule and life under communism changed considerably over time, successive 
generations experienced communism in rather different ways, and their modes of dealing with communism and its heritage will likely differ accordingly.

\section{References}

Aboim, S., and Vasconcelos, P. (2014) 'From Political to Social Generations: a Critical Reappraisal of Mannheim's Classical Approach', European Journal of Social Theory 17 (2): 165-183.

Anonymised (2014)

Bernhard, M., and Kubik, J. (2014) Twenty Years after Communism: The Politics of Memory and Commemoration. Oxford: Oxford University Press.

Bolin, G. (2014) 'Media Generations: Objective and Subjective Media Landscapes and Nostalgia among Generations of Media Users', Participations: Journal of Audience \& Reception Studies 11(2): 108-131.

Bourdon, J. (2003) 'Some Sense of Time: Remembering Television', History \& Memory 15 (2): 5-35.

Bourdon, J., and Klingler-Vilenchik, N. (2011) 'Together, Nevertheless: Television Memories in Mainstream Jewish Israel', European Journal of Communication 26(1): 33-47.

Carvalheiro, J. R., and Silveirinha, M. J. (2015) 'Acting on the Body of the Audience: Dictatorship, hegemony, and gender censorship in Portugal', Feminist Media Studies 15 (5), 747-762.

Dhoest, A. (2007) 'Identifying with the Nation: Viewer Memories of Flemish TV Fiction', European Journal of Cultural Studies 10(1): 55-74.

Gumpert, G., and Cathcart, R. (1985) 'Media Grammar, Generations, and Media Gaps', Critical Studies of Mass Communication 2(1): 23-35.

Hirsch, M. (1996) 'Past Lives: Postmemories in Exile', Poetics Today 17(4): 659-686.

Huyssen, A. (1995) Twilight Memories: Making Time in a Culture of Amnesia, New York: Routledge.

Imre, A. (2016) TV Socialism, Durham, NC: Duke University Press.

Jennings, M.K., and Zhang, N. (2005) 'Generations, Political Status, and Collective Memories in the Chinese Countryside', The Journal of Politics 67(4): 1164-1189.

Kapczynski, J. (2007) 'Negotiating Nostalgia: The GDR Past in Berlin in in Germany and Good Bye, Lenin!', The Germanic Review: Literature, Culture, Theory 82(1): 78-100.

Kaun, A., and Stiernstedt, F. (2012) Media Memories: The Case of Youth Radio DT64', Participations: Journal of Audience \& Reception Studies 9(2): 337-359. 
Keightley, E. (2011) 'From Dynasty to Songs of Praise: Television as Cultural Resource for Gendered Remembering', European Journal of Cultural Studies 14(4): 395-410.

Keightley, E., and Pickering, M. (2012) The Mnemonic Imagination: Remembering as a Creative Practice, Basingstoke: Palgrave Macmillan.

Khinkulova, K. (2012) 'Hello, Lenin? Nostalgia on Post-soviet Television in Russia and Ukraine', VIEW - Journal of European Television History and Culture 1(2): 94-104. Kotański, J. (2004) 'Obraz Historii Polski w Kinie i Telewizji PRL', in Marek Malinowski (ed.) Media w PRL, PRL w Mediach, Gdańsk: Uniwersytet Gdański.

Lepp, A., and Pantti, M. (2013) 'Window to the West: Memories of Watching Finnish Television in Estonia During the Soviet Period', VIEW - Journal of European Television History and Culture 2(3): 76-86.

Łukowski, M. (1980) Film Seryjny W Programie Telewizji Polskiej: (lata 1959-1970), Wydawnictwa Radia i Telewizji.

Mannheim, K. (1952[1927]) 'The Problem of Generations', in Paul Kecskemeti (ed.) Essays on the Sociology of Knowledge, New York: Oxford University Press, pp. 276-322.

Mark, J. (2010) The Unfinished Revolution: Making Sense of the Communist Past in CentralEastern Europe, New Haven, CT: Yale University Press.

Maass, M., and González, J.A. (2005) 'Technology, Global Flows and Local Memories:

Media Generations in Global Mexico', Global Media and Communication 1(1): 105-122.

Media2.pl (2007) Czterej pancerni... w Polsacie. Available from

http://media2.pl/media/19498-Czterej-pancerni...-w-Polsacie.html 29.01.2007. [13 July 2015]

Nora, P. (1996) Realms of Memory: Conflicts and Divisions. Vol.1 New York: Columbia University Press.

Pawełczyńska, A. (1975) Wojna i okupacja w pamięci pokoleń, Warszawa: Ośrodek Badania Opinii Publiczne i Studiów Programowych.

Penati, C. (2013) Il focolare elettronico: Televisione italiane dalle origini e cultura di visione, Milano: Vita e pensiero.

Piotrowski, P. K. (2011) Kultowe Seriale, Wydawnictwo: Prószyński i S-ka.

RTV Radio i Telewizja (1969) 'Radio i TV w Służbie Partii i Narodu' in RTV Radio $i$ Telewizja, nr 21, 1969.

Ramsay, D. (2015) American Media and the Memory of World War II, London and New York: Routledge.

Reifová, I. (2015) 'A Study in the History of Meaning-making: Watching Socialist Television Serials in the Former Czechoslovakia', European Journal of Communication 30(1): 79-94. 
Reifová, I., Gillárová, K., and Hladík, R. (2012) 'The Way We Applauded: How Popular Culture Stimulates Collective Memory of the Socialist Past in Czechoslovakia: The Case Study of the Television Serial Vyprávěj and its Viewers', in Imre, A., Havens, T. and Lustyik, K. (eds.) Popular Television in Eastern Europe During and Since Socialism, London: Routledge, pp. 199-221.

Reifová, I., and Hladík, R. (2013) 'Uncertain Guilt: How the Czech Television Serial Vyprávěj Strred Up Viewers' Memories of Socialism', in Tomanić Trivundža, I., Carpentier, N., Nieminen, H., Pruulmann-Venerfeldt, P., Kilborn, R., Sundin, E., and Olsson, T. (eds.) Past, Future and Change: Contemporary Analysis of Evolving Media Scapes, Ljubljana: Založba DFV, pp. 197-107.

Rutten, E., Fedor, J., and Zvereva, V. (eds.) (2013) Memory, Conflict and New Media: Web Wars in Post-Socialist States. London: Routledge.

Sarkisova, O., and Apor, P. (eds.) (2008) Past for the Eyes East European Representations of Communism in Cinema and Museums after 1989, Budapest: Central European University Press.

Schuman, H., and Scott, J. (1989) 'Generations and Collective Memories,' American Sociological Review 53(3): 359-381.

Todorova, M., Dimou, A., and Troebst, S. (eds.) (2014) Remembering Communism: Private and Public Recollections of Lived Experience in Southeast Europe, Budapest: Central European University Press.

Volčič, Z. (2007) 'Yugo-nostalgia: Cultural Memory and Media in the Former Yugoslavia,' Critical Studies in Media Communication 24(1): 21-38.

Volkmer, I. (ed.) (2006) News in Public Memory: An International Study of Media Memories across Generations, Bern: Peter Lang.

Westlund, O., and Weibull, L. (2013) 'Generation, Life Course and News Media Use in Sweden 1986-2011', Northern Lights 11: 147-173.

Wirtualne Media (2007) TVP1: 'Pancerni' sa bezkonkurencyjni, available from: http://www.wirtualnemedia.pl/artykul/tvp1-pancerni-sa-bezkonkurencyjni, accessed 15 August 2015.

Wirtualne Media (2006) Nie z nami te numery, Bronek!, available from: http://www.wirtualnemedia.pl/artykul/nie-z-nami-te-numery-bronek, accessed 15 August 2015. 